GRASAS Y ACEITES 71 (1)

January-March 2020, e338

ISSN-L: 0017-3495

https://doi.org/10.3989/gya.1051182

\title{
Determination of bovine tallow in butter using a comprehensive method
}

\author{
Z. Nilchian ${ }^{\mathrm{a}}$, M.R. Ehsani ${ }^{\mathrm{a}, 凶}$, Z. Piravi-Vanak ${ }^{\mathrm{b}, \varpi}$ and H. Bakhoda $^{\mathrm{c}}$ \\ ${ }^{a}$ Department of Food Science and Technology, Science and Research Branch, Islamic Azad University, Tehran, Iran. \\ ${ }^{b}$ Research Department of Food Technology and Agricultural Products, Standard Research Institute of Iran, Karaj, Iran. \\ ${ }^{c}$ Department of Agricultural Mechanization, Science and Research Branch, Islamic Azad University, Tehran, Iran. \\ ${ }^{\square}$ Corresponding authors: m-ehsani@srbiau.ac.ir; zpiravi@gmail.com
}

Submitted: 14 October 2018; Accepted: 21 February 2019; Published online: 13 January 2020

SUMMARY: The detection of animal fats such as tallow in butter using standard criteria is more difficult than vegetable fats. In order to perform a complete assessment, several methods are likely to be used together. In the experimental design of this research, compositional characteristics such as fatty acids, sterols and triacylglycerols, along with the conventional physicochemical characteristics of butter mixed with different percentages of tallow $(0-15 \% \mathrm{w} / \mathrm{w})$ were evaluated. An increase of less than $5 \%(\mathrm{w} / \mathrm{w})$ in bovine tallow content in butter physicochemical tests, sterols and fatty acids could not indicate the adulteration level but the ratio of $\mathrm{C}_{6+8+10+12} /$ $\mathrm{C}_{18}$ fatty acids, $\mathrm{C}_{52} / \mathrm{C}_{50} \cdot \mathrm{C}_{52} / \mathrm{C}_{48}, \mathrm{C}_{52} / \mathrm{C}_{46}$ triacylglycerols, $\mathrm{S} 1$, S3, S5-value equation and $\mathrm{C}_{52}$ triacylglycerols could show this adulteration level in butter. Also, the successive use of fatty acids and triacylglycerols resulted in the capability to determine adulteration in butter including bovine tallow above $1 \%(\mathrm{w} / \mathrm{w})$.

KEYWORDS: Bovine tallow; Fatty acid; Pure butter; Sterols; Triacylglycerols

SUMMARY: Determinación de sebo bovino en mantequilla utilizando un método integral. La detección de grasas animales, como el sebo en mantequilla, utilizando criterios estándares es más difícil que las grasas vegetales y esto probablemente se puede evaluar mediante la recopilación de métodos de evaluación y mediante un enfoque completo. En el diseño experimental de esta investigación, se evaluaron las características composicionales como los ácidos grasos, esteroles y triacilgliceroles junto con los índices fisicoquímicos convencionales, en mantequilla mezclada con un porcentaje diferente de sebo $(0-15 \% \mathrm{p} / \mathrm{p})$. Mediante un aumento de menos del $5 \%$ $(\mathrm{p} / \mathrm{p})$ de contenido de sebo bovino en mantequilla, las pruebas fisicoquímicas, los esteroles y los ácidos grasos no pudieron indicar el nivel de adulteración, pero sí lo hizo la relación de ácidos grasos $\mathrm{C}_{6+8+10+12} / \mathrm{C}_{18}$, la relación de triacilgliceroles $\mathrm{C}_{52} / \mathrm{C}_{50} ; \mathrm{C}_{52} / \mathrm{C}_{48} ; \mathrm{C}_{52} / \mathrm{C}_{46}$; los valores de S1, S3, S5 en la ecuación y los triacilgliceroles C52. Además, el uso sucesivo de ácidos grasos y triacilgliceroles dio como resultado la capacidad de determinar la adulteración en la mantequilla, incluido el sebo bovino por encima del 1\% (p/p).

PALABRAS CLAVE: Ácido graso; Esteroles; Mantequilla pura; Sebo bovino; Triacilgliceroles

ORCID ID: Nilchian Z https://orcid.org/0000-0002-7026-8972, Ehsani MR https://orcid.org/0000-0002-5999-1238, Piravi-Vanak Z https://orcid.org/0000-0002-0771-3041, Bakhoda H https://orcid.org/0000-0002-5681-9539

Citation/Cómo citar este artículo: Nilchian Z, Ehsani MR, Piravi-Vanak Z, Bakhoda H. 2020. Determination of bovine tallow in butter using a comprehensive method. Grasas Aceites 71 (1), e338. https://doi.org/10.3989/gya.1051182

Copyright: (C2020 CSIC. This is an open-access article distributed under the terms of the Creative Commons Attribution 4.0 International (CC BY 4.0) License. 


\section{INTRODUCTION}

Milk fat is a dietary fat which provides energy and is a source of soluble vitamins, antioxidants and bioactive compounds; hence, it has high nutritional value (Palmquist, 2006). About 416 fatty acids have been found in bovine milk fat, of which $40-60 \%$ are high-chain (predominantly $\mathrm{C}_{18}$ ) and derived from the diet (Jensen, 2002; Palmquist, 2006). Milk fat, one of the most important dietary sources, contains about $96 \%$ triglycerides, $1.5 \%$ diglycerides, $0.3 \%$ monoglycerides and $0.2 \%$ phospholipids, free fatty acids, carotenoids and soluble-in-fat vitamins (IDF, 2008). This fat contains a mixture of triacylglycerols and a few other fats whose biological and physical properties can be influenced by the carbon numbers of each of the three fatty acids, unsaturation content, position and shape of double bonds and distribution of any three fatty acids in the triacylglycerol structure (Hocquette and Gigil, 2005).

Butter obtained from milk fat is valued by a wide range of consumers due to its suitable taste and nutritional value. Any changes to the natural characteristics of butter, specifically $66 \%$ saturated fatty acids, 30\% monounsaturated fatty acid and $4 \%$ polyunsaturated fatty acids, produces a product which is unacceptable to consumers (IDF, 2008). Adding non-milk fat into milk and milk products is an out-dated process which can alter the main compositions of fatty acids, triacylglycerols and sterols compared to standard limits and change the lipid profile and nutritional value due to the addition of foreign agents into the butter. These changes may even endanger the health of consumers (Mahlenbacher, 1960).

The fatty acid profile has been examined in various fats and oils but this information is insufficient in terms of combinations of fats or oils because different mixtures of triacylglycerols in suitable ratios can lead to similar fatty acid profiles and for this reason, recent studies usually use triacylglycerols as indicators to determine oils and fats. In nature, butyric acid occurs exclusively in milk fat and enables quantitative estimations of low to moderate amounts of milk fat in vegetable and animal fats. However, due to the large variation in fatty acids, it is difficult to provide qualitative and quantitative information about foreign fat in pure butter but triacylglycerols are more stable than fatty acids under different conditions (Montealegre et al., 2010; ISO, 17678). In 1877, the Leipezig Pharmaceutical Union Committee proposed 800 indexes to discover reliable and practical diagnostic methods for the determination of butter adulteration with other fats (Nollet and Toldra, 2010). Research for improving analytical methods to determine butter adulteration is very difficult. Based on this, a collection of assessment methods in succession or together can identify and distinguish foreign fats, including tallow from butter fat. Since the identification of animal-stored fats is more complicated than vegetable fat, the use of multiple methods together is indispensable.

At present, collected texts from international standards such as the Codex standard on food have introduced the identification principles of butter purity as methods of conventional physicochemical tests and do not include the use of sensitive or differential tests to determine butter purity within the limits of international standards. This is due to the limited scope of studies, and lack of a comprehensive method to achieve definitive and correct outcomes to determine purity, and adulteration traceability of milk fat compounds and in particular butter. So this issue would cause an increase in the possibility of adulteration in butter (Codex Stan, 279). However, in similar cases, for example to determine authenticity and trace the adulterations and purity of olive oil, the International Codex Standard has assigned multiple detection tests and the limits of precise determination related to sensitive analyses as a base for determining the authenticity of product in the world which confirm the necessity of applying a precise assay to trace adulterations such as fatty acid composition, triacylglycerol composition and content, saturated fatty acid at the second position of triacylglycerols, sterol compositions, metal contents, relative density, refractive index, saponification value, and iodine value, among others (Codex Stan, 33). To determine the authenticity and purity of butter, International Standard ISO 17678 has specified a reference method for the determination of milk fat purity using a gas chromatographic analysis of triglycerides. Both vegetable oil and animal fats such as beef tallow and lard can be detected by using defined triacylglycerol (TAG) equations (S-values) which are calculated from TAG percentages. For detection of foreign fat, the S-value equations are compared with the corresponding S-limits. If any $\mathrm{S}$-value is outside the corresponding limits, the sample will contain a foreign fat. Basically, the method applies to milk fat, regardless of feeding, breed or lactation conditions. In this regard, the fatty acid composition, in two positions of the Triacylglycerols of different tallow types for detecting tallow mixtures is not necessary.

Therefore, with manipulations and adulterations in butter and the production of a low-quality product and the importation of about $95 \%$ of products with indefinite property, especially in combination with animal fat such as tallow, a comprehensive and effective analytical protocol is required to evaluate butter. The determination of fatty acid profile, sterol composition and triacylgycerol percentage together can result in a complete and comprehensive evaluation. The aim of this study is to find a comprehensive method for tracing the main and minor indexes of pure butter and samples combined with animal fat, especially bovine tallow. 


\section{MATERIALS AND METHODS}

\subsection{Sample preparation}

A milk sample from a Holstein calf, collected at the end of the third month in spring was used to avoid the fluctuation of season changes in milk fat composition levels. From this milk sample, pure butter was prepared by separator according to the method of a butter producing factory. The butter obtained was put in $100 \mathrm{ml}$ plastic containers and kept at ${ }^{\circ} 20^{\circ} \mathrm{C}$ until analysis. The fat from a Holstein bovine tallow sample was extracted by rotary at $50{ }^{\circ} \mathrm{C}$ and then filtered with common filter paper (Kumar et al., 2015). The fat of the pure butter samples was extracted according to ISO 17678 and kept in glass containers under freezer conditions of $-20{ }^{\circ} \mathrm{C}$. In order to prepare an adulterated mixture, pure butter fat was mixed with bovine tallow based on weight percentages $(0 \%, 1.18 \%, 2.63 \%, 4.40 \%, 6.06 \%, 7.50 \%, 9.94 \%$, $12.38 \%, 13.69 \%$ and $15 \% \mathrm{w} / \mathrm{w})$.

\subsection{Slip melting point}

Slip melting point was determined using tubes of the melting point method according to AOCS Cc 3-25.

\subsection{Density and viscosity}

Density and viscosity were determined according to Dardiri, (1985).

\subsection{Refractive index}

The refractive index of the samples was measured using a refractometer at $40{ }^{\circ} \mathrm{C}$ with ISO 6320 standard.

\subsection{Acid, iodine and saponification values}

The acid value of the butter samples was measured under the ISO 660 standard. Their iodine value was measured by the vijz method according to ISO 3961 standard and the saponification value was determined according to the AOCS Cd3b-76 standard.

\subsection{Sterols}

Sterol compositions were determined with GC under Commission Regulation (EC) No 273/2008.

\subsection{Fatty acids analysis}

Fat extraction from different treatments was carried out and fatty acid was analyzed according to gas chromatography with the column of
Dikmacap-2330 $(60 \mathrm{~m} \times 0.25 \mathrm{~mm} \times 0.2 \mu \mathrm{m})$ and based on the International Standard ISO 15885.

\subsection{Triacylglycerols analysis}

The triacylglycerol analysis was carried out in accordance with International Standard draft ISO 17678 by specific triacylglycerol equations. In general, this method is applied for milk or products made from milk, regardless of nutrition, breed and lactation. The purity of milk fat was determined in the triacylglycerol content using S-values. In this regard, the fat extracted from butter by GC was analyzed using a capillary column (Dikma-SHT, $15 \mathrm{~m} \times 0.53 \mathrm{~mm} \times 0.15 \mu \mathrm{m}$ with a non-polar stationary phase that can withstand temperatures of up to $400{ }^{\circ} \mathrm{C}$ ) to determine glycerides. By inserting the mass percentage of fatty molecules with different sizes, S-value equations were calculated to determine triacylglycerols. In addition, the ratio of triacylglycerols was determined.

\subsection{Statistical analysis}

To examine authenticity percentages, experiments were designed by response surface methodology with statistical software from Design Expert 8. ANOVA in this methodology was used to evaluate significant differences, Adj R-Squared, $\mathrm{CV} \%$ and L-Pseudo equations (significance levels at $\mathrm{p}<0.05$ ). For each treatment, experiments were repeated three times. This statistical method made an attempt to predict the optimal point of authenticity.

\section{RESULTS}

\subsection{Slip melting point}

The data obtained from the slip melting point indicated that adding different contents of bovine tallow to butter resulted in a significant difference at the $95 \%$ level in relation to the slip melting point. Bovine tallow added to butter produced an increase in the slip melting point from 34 to $38^{\circ} \mathrm{C}$. According to the results, it was found that by changing the slip melting points in the samples, the adulteration level in butter including various contents of bovine tallow was not detectable but according to the $\mathrm{R}^{2}$ value, this factor could estimate $84 \%$ of the presence of foreign fat.

\subsection{Density and viscosity}

The data obtained for density and viscosity indicated that adding different contents of bovine tallow to butter resulted in a significant difference at the $95 \%$ level in relation to density and viscosity. Bovine tallow added to butter produced a reductio in these factors. By increasing bovine tallow in 
butter, the density at $20{ }^{\circ} \mathrm{C}$ relative to water at 20 ${ }^{\circ} \mathrm{C}$ decreased from 0.9326 to 0.8520 and by increasing bovine tallow in the range of $0-8 \%$, the viscosity content also decreased from 58 to 46 centipoise (cP). However, by increasing the bovine tallow above $8 \%$, it rose to $53 \mathrm{cP}$. According to the $\mathrm{R}^{2}$ value, density and viscosity were able to estimate the presence of foreign fat at $91 \%$ and $93 \%$, respectively but the adulteration level in the butter was not detectable.

\subsection{Refractive index}

The data from the refractometer related to refractive index and brix percentage, adding different contents of bovine tallow in butter indicated a significant difference at $95 \%$ in relation to the refractive index which was not observed with respect to brix percentage. Both types of oil had a positive effect on refractive index but none of the oils had a dominant effect separately. According to the results and standard limits of this factor for pure butter (Iranian national Standard, 162), the change in refractive index was not able to reveal the adulteration level in the butter including various amounts of bovine tallow in the samples.

\subsection{Identification of acid, iodine and saponification value}

According to the data for the acid, iodine and saponification values for each treatment, it was found that adding bovine tallow to butter caused a significant difference at the $95 \%$ level in relation to these three factors. Given the statistical results of the L-Pseudo equations, the coefficients of tallow and butter fat and also their effect on each other were identified.

The acid value decreased slightly, within the range of the Iranian national standard but based on the L-Pseudo equation, the increase in tallow did not indicate a greater effect on changes in this factor (Iranian national standard, 162).
Based on the L-Pseudo equation, the increase in bovine tallow had a greater effect on the increase in the iodine value. By increasing bovine tallow in the range of $0-11.5 \%$, the iodine value increased up to 43.62 and by increasing bovine tallow above $12 \%$, it decreased to about 42.93. In this equation both types of oil had an interaction with each other in relation to iodine value.

In addition, with respect to saponification value, the increase in bovine tallow had a greater effect on the increase in this factor, although both types of oil had interactions with each other. By increasing bovine tallow in butter to $5.5 \%$, the saponification value was about 235 and by increasing bovine tallow above $5.5 \%$ this factor increased to about 367 . Based on the $\mathrm{R}^{2}$ value, it was indicated that the saponification value had $92 \%$ capability of estimation in relation to added bovine tallow (Table 1). Based on the results obtained and standard limits of these factors in pure butter (Iranian national standard, 162), the changes in acid and iodine values were able to indicate the adulteration level in butter including bovine tallow above $15 \%$ and $5 \%$, respectively, but the saponification value did not have ability to determine the level of adulteration.

\subsection{Sterols}

The contents of vegetable sterol and cholesterol were measured. Based on the results for the effects of different treatments of adding bovine tallow percentages to butter on vegetable sterol as well as on cholesterol, it was found that significant differences at the $95 \%$ level were not observed for cholesterol but there was a significant difference for vegetable sterol. By increasing bovine tallow in butter, the cholesterol level remained approximately constant $(0.18 \%)$ but the sterol content decreased from 1.6 to $0.8 \%$. Based on the results and standard limits for this factor in pure butter (Iranian national Standard, 162), a change in sterols could not show the adulterated level in butter including bovine tallow.

TABLE 1. Analysis of variance according to response surface methodology for the effect of adding different contents of bovine tallow to butter on acid, iodine and saponification value $(\mathrm{P}<0.05)$

\begin{tabular}{lccl}
\hline Parameters & Prob $>\mathbf{F}^{*}$ & \% C.V & \multicolumn{1}{c}{ L_Pseudo equation** } \\
\hline Acid Value & 0.0088 & 0.84 & (acid value) $=0.37 \mathrm{~A} * * *+0.38 \mathrm{~B} * * *\left(\mathrm{R}^{2}=0.3352\right)$ \\
Iodine Value & 0.0004 & 7.66 & (iodine value) $=42.93 \mathrm{~A}+33.04 \mathrm{~B}+16.68 \mathrm{AB}\left(\mathrm{R}^{2}=0.6288\right)$ \\
Saponification Value & 0.0001 & 5.87 & $\begin{array}{l}\text { (saponification value })=367.77 \mathrm{~A}+232.87 \mathrm{~B}-229.89 \mathrm{AB}+ \\
\end{array}$ \\
& & 373.46AB $(\mathrm{A}-\mathrm{B})\left(\mathrm{R}^{2}=0.9199\right)$
\end{tabular}

All determinations were carried out in triplicate.

*Values of "Prob > F" less than 0.05 indicate model terms are significant.

**The equation in terms of coded factors can be used to make predictions about the response of given levels of each factor. The coded equation is useful for identifying the relative impact of the factors by comparing factor coefficients.

***A: added tallow coefficient and B: butter coefficient. 


\subsection{Fatty acids analysis}

The evaluation of the fatty acid percentage profile for each treatment is shown in Table 2.
According to the statistical analysis, the addition of bovine tallow to butter had a significant difference at the $95 \%$ level for the percentages of $\mathrm{C}_{4: 0}$, $\mathrm{C}_{6: 0}, \mathrm{C}_{8: 0}, \mathrm{C}_{10: 0}, \mathrm{C}_{10: 1}, \mathrm{C}_{11: 0}, \mathrm{C}_{12: 0}, \mathrm{C}_{14: 0}, \mathrm{C}_{14: 1}, \mathrm{C}_{16: 0}$,

TABLE 2. The fatty acid percentage in each treatment with different amounts of bovine tallow according to GC

\begin{tabular}{|c|c|c|c|c|c|c|c|c|c|c|}
\hline Tallow \% & $\mathbf{0}$ & 1.18 & 2.63 & 4.4 & 6.06 & 7.5 & 9.94 & 12.38 & 13.69 & 15 \\
\hline C4:0 & 1.36 & 1.67 & 1.29 & 1.43 & 1.35 & 0.71 & 0.52 & 0.89 & 0.21 & 1.24 \\
\hline C6:0 & 1.17 & 1.33 & 1.11 & 1.23 & 1.15 & 0.62 & 0.43 & 0.84 & 0.18 & 1.04 \\
\hline C8:0 & 1.04 & 0.93 & 0.86 & 0.9 & 0.82 & 0.47 & 0.31 & 0.54 & 0.13 & 0.79 \\
\hline C10:0 & 2.07 & 2.14 & 2.04 & 2.12 & 1.92 & 1.17 & 0.79 & 1.92 & 0.34 & 1.84 \\
\hline C10:1 & 0.27 & 0.25 & 0.21 & 0.24 & 0.22 & 0.12 & 0.08 & 0.28 & 0.03 & 0.27 \\
\hline C11:0 & 0.06 & 0.06 & 0.05 & 0.06 & 0.05 & 0.03 & 0.02 & 0.02 & 0.01 & ND \\
\hline $\mathrm{C} 12: 0$ & 2.61 & 2.7 & 2.58 & 2.69 & 2.41 & 1.52 & 0.92 & 2.37 & 0.43 & 2.28 \\
\hline C13:0 & 0.12 & 0.12 & 0.11 & 0.12 & 0.11 & 0.06 & 0.04 & 0.05 & 0.02 & ND \\
\hline C14:0 & 9.89 & 9.85 & 9.66 & 9.84 & 9.01 & 7.05 & 4.49 & 7.32 & 3.31 & 9.41 \\
\hline C14:1 & 1.56 & 1.68 & 1.27 & 1.7 & 1.58 & 1.31 & 0.86 & 1.12 & 0.67 & 1.07 \\
\hline C15:0 & 1.20 & 1.31 & 1.12 & 1.31 & 1.21 & 0.91 & 0.66 & 1.04 & 0.48 & 1.04 \\
\hline C15:1 & 0.36 & 0.35 & 0.37 & 0.38 & 0.35 & 0.27 & 0.27 & 0.36 & 0.23 & 0.37 \\
\hline C16:0 & 32.49 & 31.93 & 32.46 & 31.27 & 30.85 & 31.22 & 26.86 & 28.77 & 25.24 & 31.26 \\
\hline C16:1 & 2.94 & 3.54 & 2.8 & 3.62 & 3.6 & 3.68 & 3.59 & 2.78 & 3.7 & 2.84 \\
\hline C17:0 & 0.80 & 0.78 & 0.7 & 0.81 & 0.83 & 0.95 & 1.09 & 0.84 & 1.25 & 0.89 \\
\hline $\mathrm{C} 17: 1$ & 0.43 & 0.46 & 0.45 & 0.48 & 0.49 & 0.30 & 0.62 & 0.40 & 0.73 & 0.4 \\
\hline C18:0 & 10.37 & 10.61 & 10.38 & 10.5 & 11.68 & 15.08 & 18.52 & 11.51 & 21.07 & 12.17 \\
\hline $\mathrm{C} 18: 1 \mathrm{t}$ & 2.08 & 0.89 & 1.93 & 1.02 & 1.62 & 1.28 & 0.91 & 1.50 & 0.79 & 1.86 \\
\hline $\mathrm{C} 18: 1 \mathrm{c}$ & 23.66 & 22.96 & 23.44 & 23.44 & 24.05 & 28.29 & 32.56 & 28.53 & 35.65 & 24.97 \\
\hline $\mathrm{C} 18: 2 \mathrm{t}$ & 0.27 & 0.43 & 0.65 & 0.77 & 0.7 & 0.27 & 0.62 & 0.30 & 0.65 & 0.26 \\
\hline $\mathrm{C} 18: 2 \mathrm{c}$ & 3.1 & 2.64 & 2.71 & 2.67 & 2.62 & 2.02 & 2.27 & 2.85 & 2.12 & 2.9 \\
\hline C20:0 & 0.21 & 0.23 & 0.19 & 0.22 & 0.23 & 0.21 & 0.26 & 0.2 & 0.27 & 0.2 \\
\hline C18:3n6 & ND & ND & ND & ND & 0.01 & ND & ND & ND & ND & ND \\
\hline $\mathrm{C} 18: 3 n 3$ & 0.55 & 0.45 & 0.41 & 0.44 & 0.42 & 0.32 & 0.34 & 0.50 & 0.31 & 0.54 \\
\hline C20:1 & 0.46 & 0.16 & 0.47 & 0.16 & 0.16 & 0.09 & 0.15 & 0.30 & 0.15 & 0.41 \\
\hline $\mathrm{C} 21: 0$ & 0.03 & 0.01 & 0.06 & 0.01 & 0.02 & 0.01 & 0.02 & 0.09 & 0.03 & 0.06 \\
\hline C20:2 & 0.01 & 0.03 & 0.01 & 0.01 & 0.01 & 0.02 & 0.02 & 0.04 & 0.02 & 0.02 \\
\hline C22:0 & 0.1 & 0.19 & 0.18 & 0.18 & 0.18 & 0.14 & 0.14 & 0.12 & 0.15 & 0.09 \\
\hline $\mathrm{C} 22: 1$ & 0.03 & 0.02 & 0.02 & 0.03 & 0.03 & 0.02 & 0.08 & 0.05 & 0.02 & ND \\
\hline C20:3n6 & ND & ND & ND & ND & ND & ND & ND & ND & ND & ND \\
\hline $\mathrm{C} 20: 3 \mathrm{n} 3$ & ND & ND & ND & ND & ND & ND & ND & ND & ND & ND \\
\hline C20:4n6 & 0.06 & 0.05 & 0.05 & 0.01 & 0.03 & 0.03 & 0.04 & 0.09 & 0.01 & ND \\
\hline $\mathrm{C} 22: 2$ & 0.05 & 0.01 & 0.04 & 0.04 & 0.06 & 0.08 & 0.01 & 0.16 & 0.01 & 0.08 \\
\hline C24:0 & 0.04 & 0.05 & 0.04 & 0.04 & 0.04 & 0.10 & 0.02 & 0.06 & 0.03 & 0.04 \\
\hline $\mathrm{C} 20: 5 \mathrm{n} 3$ & ND & ND & ND & ND & ND & ND & ND & ND & ND & ND \\
\hline C24:1 & ND & 0.06 & 0.02 & 0.05 & 0.05 & 0.12 & 0.01 & 0.07 & 0.03 & 0.03 \\
\hline $\mathrm{C} 22: 5 \mathrm{n} 3$ & 0.06 & 0.08 & 0.03 & 0.07 & 0.07 & 0.04 & 0.1 & 0.08 & 0.07 & 0.02 \\
\hline $\mathrm{C} 22: 6 \mathrm{n} 3$ & 0.02 & 0.01 & 0.02 & 0.01 & 0.01 & 0.01 & 0.02 & 0.1 & 0.02 & 0.02 \\
\hline CLAc9t11 & 0.54 & 0.62 & 0.78 & 0.6 & 0.61 & 0.35 & 0.5 & 0.43 & 0.4 & 0.41 \\
\hline CLAt10c12 & 0.02 & 0.01 & 0.06 & 0.01 & 0.01 & 0.01 & ND & 0.08 & 0.08 & 0.05 \\
\hline
\end{tabular}

All determinations were carried out in triplicate

*ND: not detected. 
$\mathrm{C}_{17 \cdot 0}, \mathrm{C}_{17 \cdot 1,}, \mathrm{C}_{18 \cdot 0}, \mathrm{C}_{18 \cdot 1 \mathrm{C}}$ and CLA 9 at11 fatty acids; while this difference was not observed in other fatty acids. Based on the L-Pseudo equations for $\mathrm{C}_{4: 0}$, $\mathrm{C}_{6: 0}, \mathrm{C}_{8: 0}, \mathrm{C}_{10: 0}, \mathrm{C}_{10: 1}, \mathrm{C}_{11: 0}, \mathrm{C}_{12: 0}, \mathrm{C}_{14: 0}, \mathrm{C}_{14: 1}, \mathrm{C}_{16: 0}$ and $\mathrm{CLA}_{\mathrm{cgt11}}$ fatty acids, generally both types of bovine tallow fat and butter had a positive effect on fatty acids percentages. which by increasing the fat percentage of bovine tallow in butter, lowered the content of these fatty acids; although the equations of $\mathrm{C}_{17: 0}, \mathrm{C}_{17: 1}, \mathrm{C}_{18: 0}$ and $\mathrm{C}_{18: 1 \mathrm{C}}$ fatty acids indicated that by increasing the fat percentage of bovine tallow in butter, the content of these fatty acids was higher. Given the value of $\mathrm{R}^{2}$ for each factor, fatty acids could not estimate the presence of foreign added fat (Table 3). According to the results from the effect of adding various amounts of bovine tallow to butter on significant changes in different fatty acids, based on the limits identified limits for each fatty acid in butter (Iranian national standard, 162), the changes in $\mathrm{C}_{4: 0}, \mathrm{C}_{6: 0}, \mathrm{C}_{8: 0}, \mathrm{C}_{10: 0}, \mathrm{C}_{10: 1}, \mathrm{C}_{11: 0}$, $\mathrm{C}_{12: 0}, \mathrm{C}_{14: 0}, \mathrm{C}_{14: 1}, \mathrm{C}_{16: 0}, \mathrm{C}_{17: 0}, \mathrm{C}_{17: 1}, \mathrm{C}_{18: 0}$ and $\mathrm{C}_{18: 1 \mathrm{C}}$ fatty acid contents could indicate the adulteration level in butter including bovine tallow in contents above $8.5 \%, 10 \%, 12.5 \%, 7.5 \%, 6.5 \%, 6 \%, 15 \%$, $15 \%, 15 \%, 11 \%, 15 \%, 11.5 \%$ and $15 \%$, respectively, in a sample.

The ratio between the fatty acids of $\mathrm{C}_{4-14: 1} / \mathrm{C}_{15-20}$, the sum of monounsaturated, the sum of polyunsaturated, the sum of 18 carbon monounsaturated, $\mathrm{C}_{4+6+8+10}, \mathrm{C}_{12+14+16}, \mathrm{C}_{4+6+8++18}$, $\mathrm{C}_{14: 0} / \mathrm{C}_{18: 2 c}, \quad \mathrm{C}_{14: 0} / \mathrm{C}_{18: 2 \mathrm{t}}, \quad \mathrm{C}_{18: 2 \mathrm{c}} / \mathrm{C}_{18: 0}, \quad \mathrm{C}_{18: 2 t} / \mathrm{C}_{18: 0}$, $\mathrm{C}_{18: 0} / \mathrm{C}_{8: 0}, \quad \mathrm{C}_{14: 0} / \mathrm{C}_{18: 0}, \quad \mathrm{C}_{6+8+10+12} / \mathrm{C}_{18: 0}, \quad \mathrm{C}_{18: 10} / \mathrm{C}_{18: 0}$, $\mathrm{C}_{18: 1 \mathrm{t}} / \mathrm{C}_{18: 0}, \quad \mathrm{AI}=\left(\mathrm{C}_{12: 0}+4 \times \mathrm{C}_{14: 0}+\mathrm{C}_{16: 0}\right) /(\mathrm{MUFA}+$ n-6PUFA+n-3PUFA $), \quad$ TI $=\left(\mathrm{C}_{14: 0}+\mathrm{C}_{16: 0}+\mathrm{C}_{18: 0}\right) /$ $(0.5 \times$ MUFA $+0.5 \times n-6 P U F A+3 \times n-3 P U F A+n-$ $3 / n-6)$ were considered in various treatments. In this study, the ratio between the percentage of fatty acids in various treatments showed that adding the fat of bovine tallow produced a significant difference in the ratios $\mathrm{C}_{4-14: 1} / \mathrm{C}_{15-20}$, AI,MUFA, PUFA, $\mathrm{C}_{4+6+8+10}$, $\mathrm{C}_{12+14+16}, \mathrm{C}_{4+6+\ldots+18}$, MUFA-18C, $\mathrm{C}_{14: 0} / \mathrm{C}_{18: 2 \mathrm{c}}, \mathrm{C}_{18: 2 \mathrm{c}}$ $\mathrm{C}_{18: 0}, \mathrm{C}_{18: 0} / \mathrm{C}_{8: 0}, \mathrm{C}_{14: 0} / \mathrm{C}_{18: 0}, \mathrm{C}_{6+8+10+12} / \mathrm{C}_{18: 0}$ and $\mathrm{C}_{18: 1 \mathrm{c}} \mathrm{d}$ $\mathrm{C}_{18: 0}$. According to statistical results, L-Pseudo equations for MUFA, PUFA and MUFA-18C factors indicated that both types of tallow and butter fat had a positive effect on these factors but in this case, added tallow fat indicated a greater affect than butter in increasing the amount of these factors. None of the ratios between fatty acids could estimate sufficiently in relation to added tallow fat. According to the results and also based on the determined limits of each fatty acid in butter (Iranian national standard, 162), the change in the ratio contents between $\mathrm{C}_{4-14: 1} / \mathrm{C}_{15-20}, \mathrm{C}_{4+6+8+10}, \mathrm{C}_{12+14+16}, \mathrm{C}_{4+6+\ldots+18}, \mathrm{C}_{18: 0} / \mathrm{C}_{8: 0}$, $\mathrm{C}_{14: 0} / \mathrm{C}_{18: 0}$ and $\mathrm{C}_{6+8+10+12} / \mathrm{C}_{18: 0}$ fatty acids could indicate adulterated levels in butter including amounts of bovine tallow above $2.7 \%, 8.5 \%, 15 \%, 15 \%, 2.5 \%$, $2 \%$ and $1.5 \%$, respectively.

TABLE 3. Analysis of variance according to response surface methodology for the effect of adding various contents of bovine tallow to butter on significant factors of fatty acid $(\mathrm{P}<0.05)$

\begin{tabular}{|c|c|c|c|}
\hline Fatty acids & Prob $>F^{*}$ & $\% \mathbf{C . V}$ & L_Pseudo equation** \\
\hline $\mathrm{C}_{4: 0}$ & 0.0049 & 32.22 & $\left(\mathrm{C}_{4: 0}\right)=0.68 \mathrm{~A}^{* * *}+1.41 \mathrm{~B} * * *\left(\mathrm{R}^{2}=0.3818\right)$ \\
\hline $\mathrm{C}_{6: 0}$ & 0.0059 & 32.06 & $\left(\mathrm{C}_{6: 0}\right)=0.61 \mathrm{~A}+1.22 \mathrm{~B}\left(\mathrm{R}^{2}=0.3678\right)$ \\
\hline $\mathrm{C}_{8: 0}$ & 0.0022 & 34.11 & $\left(\mathrm{C}_{8: 0}\right)=0.41 \mathrm{~A}+0.98 \mathrm{~B}\left(\mathrm{R}^{2}=0.4392\right)$ \\
\hline $\mathrm{C}_{10: 0}$ & 0.0013 & 44.14 & $\left(\mathrm{C}_{10: 0}\right)^{2.6}=1.82 \mathrm{~A}+6.77 \mathrm{~B}\left(\mathrm{R}^{2}=0.4777\right)$ \\
\hline $\mathrm{C}_{10: 1}$ & 0.0445 & 38.82 & $\left(\mathrm{C}_{10: 1}\right)=0.14 \mathrm{~A}+0.25 \mathrm{~B}\left(\mathrm{R}^{2}=0.1923\right)$ \\
\hline $\mathrm{C}_{11: 0}$ & 0.0164 & 63.77 & $\left(\mathrm{C}_{11: 0}\right)=0.01 \mathrm{~A}+0.022 \mathrm{~B}+0.1 \mathrm{AB}-0.17 \mathrm{AB}(\mathrm{A}-\mathrm{B})\left(\mathrm{R}^{2}=0.4266\right)$ \\
\hline $\mathrm{C}_{12: 0}$ & 0.0009 & 43.57 & $\left(\mathrm{C}_{12: 0}\right)^{2.62}=3.23 \mathrm{~A}+12.66 \mathrm{~B}\left(\mathrm{R}^{2}=0.5011\right)$ \\
\hline $\mathrm{C}_{14: 0}$ & 0.0078 & 23.36 & $\left(\mathrm{C}_{14: 0}\right)=6.23 \mathrm{~A}+10.06 \mathrm{~B}\left(\mathrm{R}^{2}=0.3444\right)$ \\
\hline $\mathrm{C}_{14: 1}$ & 0.0002 & 15.85 & $\left(\mathrm{C}_{14: 1}\right)=0.95 \mathrm{~A}+1.58 \mathrm{~B}\left(\mathrm{R}^{2}=0.5803\right)$ \\
\hline $\mathrm{C}_{16: 0}$ & 0.0033 & 6.35 & $\left(\mathrm{C}_{16: 0}\right)=28.07 \mathrm{~A}+32.44 \mathrm{~B}\left(\mathrm{R}^{2}=0.4105\right)$ \\
\hline $\mathrm{C}_{17: 0}$ & 0.0013 & 25.78 & $\left(\mathrm{C}_{17: 0}\right)^{-2.61}=0.96 \mathrm{~A}+1.92 \mathrm{~B}\left(\mathrm{R}^{2}=0.4746\right)$ \\
\hline $\mathrm{C}_{17: 1}$ & 0.0431 & 24.51 & $\left(\mathrm{C}_{17: 1}\right)=0.56 \mathrm{~A}+0.39 \mathrm{~B}\left(\mathrm{R}^{2}=0.1953\right)$ \\
\hline $\mathrm{C}_{18: 0}$ & 0.0029 & 22.14 & $\left(\mathrm{C}_{18: 0}\right)=16.65 \mathrm{~A}+9.88 \mathrm{~B}\left(\mathrm{R}^{2}=0.4208\right)$ \\
\hline $\mathrm{C}_{18: 1 \mathrm{c}}$ & 0.0028 & 12.59 & $\left(\mathrm{C}_{18: 1 \mathrm{c}}\right)=30.55 \mathrm{~A}+22.74 \mathrm{~B}\left(\mathrm{R}^{2}=0.4239\right)$ \\
\hline $\mathrm{CLA}_{\mathrm{c} 9 t 11}$ & 0.0113 & 17.94 & $\left(\mathrm{CLA}_{\mathrm{c} 9 \mathrm{t} 11}\right)=0.42 \mathrm{~A}+0.59 \mathrm{~B}\left(\mathrm{R}^{2}=0.3143\right)$ \\
\hline
\end{tabular}

All determinations were carried out in triplicate

*Values of "Prob > F" less than 0.05 indicate model terms are significant.

**The equation in terms of coded factors can be used to make predictions about the response for given levels of each factor. The coded equation is useful for identifying the relative impact of the factors by comparing factor coefficients. ***A: added tallow coefficient and B: butter coefficient. 


\subsection{Triacylglycerol analysis}

Data from the GC analysis related to the percentage of triacylglycerols in different treatments are shown in Table 4 and in some of them, the trend of differences among triacylglycerol GC chromatograms, especially in $\mathrm{C}_{50}, \mathrm{C}_{52}$ and $\mathrm{C}_{54}$ is indicated in Figure 1. Statistical results indicated that adding the fat of tallow presented significant differences at the $95 \%$ level in $\mathrm{C}_{32}, \mathrm{C}_{34}, \mathrm{C}_{36}, \mathrm{C}_{38}, \mathrm{C}_{40}, \mathrm{C}_{42}, \mathrm{C}_{44}, \mathrm{C}_{46}$, $\mathrm{C}_{48}, \mathrm{C}_{50}, \mathrm{C}_{52}$ and $\mathrm{C}_{54}$ triacylglycerols and this difference was not observed in triacylglycerols with low molecular weight. According to L-Pseudo equations from the statistical analysis, $\mathrm{C}_{32}, \mathrm{C}_{34}, \mathrm{C}_{36}, \mathrm{C}_{38}$, $\mathrm{C}_{40}, \mathrm{C}_{42}, \mathrm{C}_{44}, \mathrm{C}_{46}$ and $\mathrm{C}_{48}$ triacylglycerols indicated that both types of tallow and butter fat had positive effects on the percentage of triacylglycerols and by increasing tallow fat percentage in butter, these triacylglycerols decreased. But L-Pseudo equations for three triacylglycerols of $\mathrm{C}_{50}, \mathrm{C}_{52}$ and $\mathrm{C}_{54}$ showed that by increasing the level of bovine tallow fat in butter, the content of these factors increased. Moreover, given the equations, it was found that with respect to $\mathrm{C}_{34}, \mathrm{C}_{42}$ and $\mathrm{C}_{44}$ triacylglycerols, both types of fat interaced with each other. Given the value of $\mathrm{R}^{2}$ for every factor, the triacylglycerols of $\mathrm{C}_{36}, \mathrm{C}_{42}, \mathrm{C}_{44}$, $\mathrm{C}_{46}, \mathrm{C}_{52}$ and $\mathrm{C}_{54}$ revealed estimation capabilities of $75 \%, 86 \%, 88 \%, 84 \%, 87 \%$ and $79 \%$, respectively, for added animal fat (Table 5). According to the results from the effect of adding various contents of bovine tallow to butter on significant changes of different triacylglycerol percentages and based on the limits of any triacylglycerols in pure butter (Jensen, 2002), the changes in the percentage contents of $\mathrm{C}_{32}, \mathrm{C}_{34}$, $\mathrm{C}_{36}, \mathrm{C}_{38}, \mathrm{C}_{40}, \mathrm{C}_{42}, \mathrm{C}_{44}, \mathrm{C}_{46}, \mathrm{C}_{48}, \mathrm{C}_{50}, \mathrm{C}_{52}, \mathrm{C}_{54}$ triacylglycerols did show adulteration levels in butter including contents of bovine tallow above $15 \%$, $15 \%, 15 \%, 15 \%, 5 \%, 6 \%, 15 \%, 3 \%, 15 \%, 3.5 \%, 1.5 \%$ and $2 \%$, respectively.

The S-value content was obtained using the percentage content of triacylglycerols in any treatment. According to the results obtained, adding different percentages of bovine tallow fat to butter indicated significant differences in S-value equations. According to the statistical analysis for any factor, the L-Pseudo equation obtained that thereby, the equations of S-value 1-5 indicated that both types of tallow and butter fat had a positive effect on $\mathrm{S}$-value factors. In relation to the S-values of 1,3 and 5, added tallow fat indicated a lower effect than butter in increasing the content of S-value equations so these decreased equations. The S-value equations of 2 and 4 indicated that added tallow fat had a greater effect than butter in increasing the S-value content and by increasing the percentage of tallow, the content of these equations increased. Given the $\mathrm{R}^{2}$ value for every 5 equations, S-values 1 and 4 had the estimation capability of $77 \%$ and $81 \%$, respectively (Table 6).

According to the results obtained and also based on the limits of every S-value equation in pure butter (ISO, 17678), changes in the contents of S1, S2, S3, S4, S5 equations could indicate an adulteration level in butter including the content

TABLE 4. The triacylglycerol percentage in each treatment with different amounts of bovine tallow according to GC

\begin{tabular}{lcccccccccc}
\hline Tallow\% & $\mathbf{0}$ & $\mathbf{1 . 1 8}$ & $\mathbf{2 . 6 3}$ & $\mathbf{4 . 4}$ & $\mathbf{6 . 0 6}$ & $\mathbf{7 . 5}$ & $\mathbf{9 . 9 4}$ & $\mathbf{1 2 . 3 8}$ & $\mathbf{1 3 . 6 9}$ & $\mathbf{1 5}$ \\
\hline C24 & 0.03 & 0.03 & 0.03 & 0.03 & 0.03 & 0.02 & 0.02 & 0.01 & 0.02 & 0.03 \\
C26 & 0.14 & 0.22 & 0.2 & 0.16 & 0.17 & 0.19 & 0.21 & 0.18 & 0.17 & 0.17 \\
C28 & 0.38 & 0.38 & 0.53 & 0.37 & 0.34 & 0.41 & 0.44 & 0.46 & 0.43 & 0.43 \\
C30 & 0.76 & 0.80 & 1.00 & 0.77 & 0.75 & 0.78 & 0.68 & 0.80 & 0.81 & 0.84 \\
C32 & 2.12 & 2.07 & 2.15 & 2.08 & 2.05 & 2.12 & 1.95 & 1.96 & 1.92 & 2.04 \\
C34 & 5.57 & 5.21 & 5.53 & 5.44 & 5.49 & 5.56 & 5.08 & 5.01 & 4.97 & 5.16 \\
C36 & 10.69 & 10.08 & 10.48 & 10.48 & 10.45 & 10.47 & 9.65 & 9.56 & 9.51 & 9.92 \\
C38 & 12.43 & 11.88 & 12.16 & 12.2 & 12.19 & 12.14 & 11.1 & 11.15 & 11.1 & 11.52 \\
C40 & 9.14 & 8.86 & 8.96 & 8.94 & 9.04 & 8.94 & 8.12 & 8.20 & 8.16 & 8.4 \\
C42 & 6.18 & 6.06 & 6.07 & 6.03 & 6.15 & 6.05 & 5.44 & 5.55 & 5.55 & 5.61 \\
C44 & 5.94 & 5.94 & 5.85 & 5.82 & 5.91 & 5.82 & 5.28 & 5.39 & 5.39 & 5.41 \\
C46 & 7.03 & 7.15 & 6.91 & 6.92 & 6.95 & 6.87 & 6.43 & 6.52 & 6.49 & 6.58 \\
C48 & 9.59 & 9.94 & 9.53 & 9.60 & 9.59 & 9.46 & 9.39 & 9.41 & 9.40 & 9.47 \\
C50 & 12.74 & 13.21 & 12.75 & 12.94 & 12.79 & 12.82 & 13.58 & 13.47 & 13.49 & 13.41 \\
C52 & 11.55 & 12.1 & 11.88 & 12.18 & 12.12 & 12.31 & 14.99 & 14.64 & 14.78 & 13.93 \\
C54 & 4.99 & 5.24 & 5.19 & 5.35 & 5.34 & 5.42 & 6.99 & 6.84 & 6.93 & 6.34 \\
\hline
\end{tabular}

All determinations were carried out in triplicate 


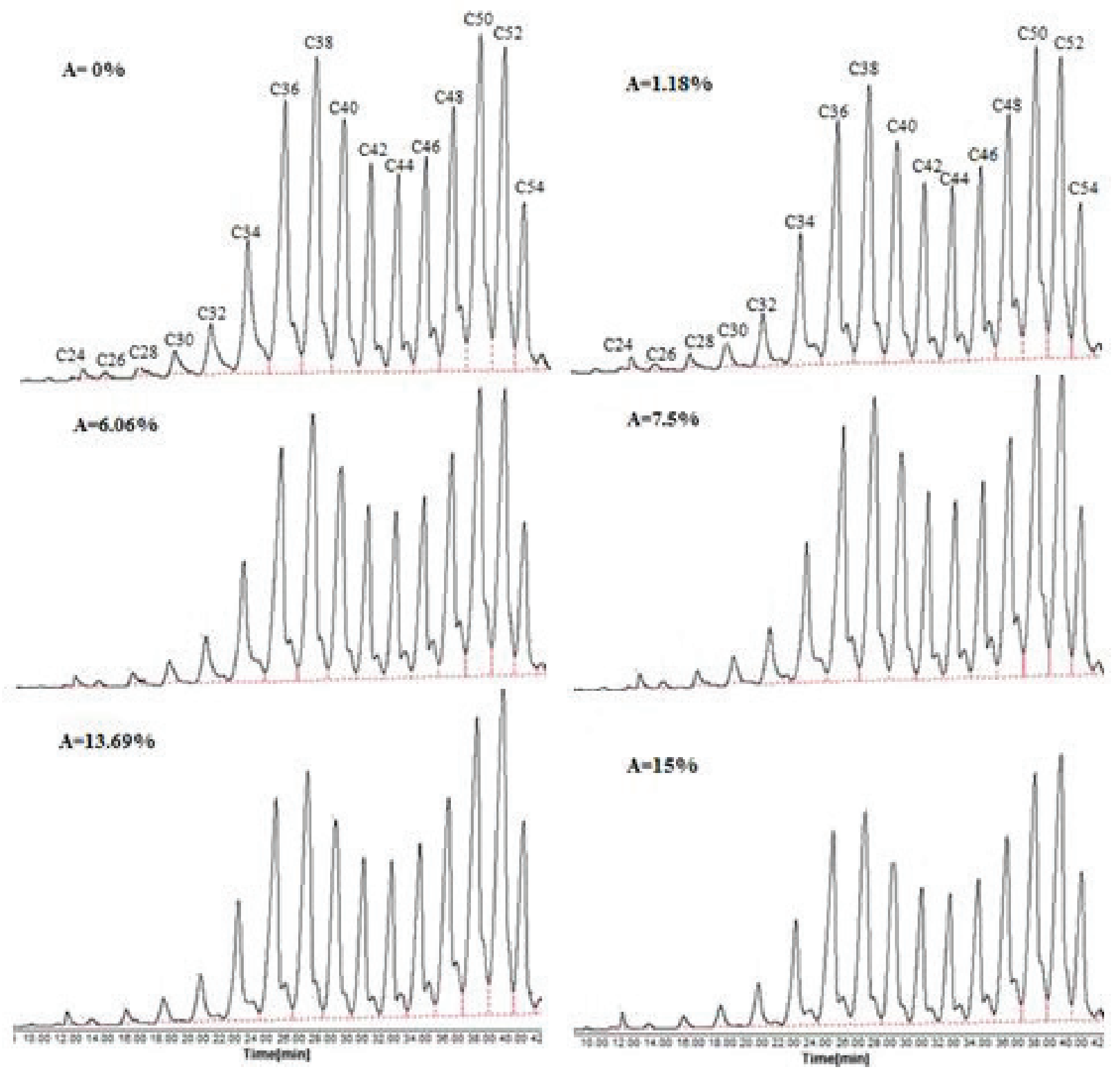

FIGURE 1. GC chromatograms resulting from the effect of adding various amounts of bovine tallow to butter on $\mathrm{C} 24$ to $\mathrm{C} 54$ triacylglycerols percentage (A: percentages of added bovine tallow).

of bovine tallow above $3.5 \%, 11.5 \%, 1.5 \%, 7 \%$ and $1 \%$, respectively, in the sample.

The ratio between triacylglycerols in the different treatments was also evaluated (Table 7) and the data obtained from these ratios indicated that adding bovine tallow fat showed a significant difference at the $95 \%$ level in the ratio between the triacylglycerols of $\mathrm{C}_{52} / \mathrm{C}_{50}, \mathrm{C}_{52} / \mathrm{C}_{54}, \mathrm{C}_{50} / \mathrm{C}_{54}, \mathrm{C}_{46} / \mathrm{C}_{54}, \mathrm{C}_{46} / \mathrm{C}_{42}$, $\mathrm{C}_{46} / \mathrm{C}_{44}, \mathrm{C}_{50} / \mathrm{C}_{46}, \mathrm{C}_{50} / \mathrm{C}_{48}, \mathrm{C}_{52} / \mathrm{C}_{48}$ and $\mathrm{C}_{52} / \mathrm{C}_{46}$. The L-Pseudo equations of $\mathrm{C}_{52} / \mathrm{C}_{54}, \mathrm{C}_{50} / \mathrm{C}_{54}$ and $\mathrm{C}_{46} / \mathrm{C}_{54}$ ratios indicated that by increasing the tallow percentage in butter, these three ratios of triacylglycerols decreased. In the L-Pseudo equations of $\mathrm{C}_{52} / \mathrm{C}_{50}$,
$\mathrm{C}_{50} / \mathrm{C}_{46}, \mathrm{C}_{50} / \mathrm{C}_{48}, \mathrm{C}_{52} / \mathrm{C}_{48}$ and $\mathrm{C}_{52} / \mathrm{C}_{46}$ ratios, it was obvious that growing tallow percentages increased these triacylglycerol ratios. In the L-Pseudo equations of $\mathrm{C}_{46} / \mathrm{C}_{42}$ and $\mathrm{C}_{46} / \mathrm{C}_{44}$ ratios, in addition to positive the effect of both tallow and butter fat on these factors and higher effect of tallow fat added with an increase in their contents, both fats interacted with each other as well. The $\mathrm{R}^{2}$ values indicated that $\mathrm{C}_{52} / \mathrm{C}_{50}, \mathrm{C}_{50} / \mathrm{C}_{54}, \mathrm{C}_{46} / \mathrm{C}_{54}, \mathrm{C}_{50} / \mathrm{C}_{46}, \mathrm{C}_{50} / \mathrm{C}_{48}, \mathrm{C}_{52} / \mathrm{C}_{48}$ and $\mathrm{C}_{52} / \mathrm{C}_{46}$ triacylglycerol ratios had a capability of estimation of $88 \%, 75 \%, 85 \%, 84 \%, 88 \%, 88 \%$ and $87 \%$, respectively, with respect to animal fat added to butter. According to the results from the effect 
TABLE 5. Analysis of variance according to response surface methodology for the effect of adding different contents of bovine tallow to butter on significant factors of triacylglycerols $(\mathrm{P}<0.05)$

\begin{tabular}{lccl}
\hline Triacylglycerols & Prob $>\mathbf{F}^{*}$ & \% C.V & \multicolumn{1}{c}{ L_Pseudo equation** $^{* *}$} \\
\hline $\mathrm{C}_{32}$ & 0.0082 & 7.40 & $\left(\mathrm{C}_{32}\right)=1.97 \mathrm{~A}^{* * *}+2.29 \mathrm{~B}^{* *}\left(\mathrm{R}^{2}=0.3409\right)$ \\
$\mathrm{C}_{34}$ & 0.0002 & 3.11 & $\left(\mathrm{C}_{34}\right)=5 \mathrm{~A}+5.68 \mathrm{~B}+1.59 \mathrm{AB}-4.56 \mathrm{AB}(\mathrm{A}-\mathrm{B})^{2}\left(\mathrm{R}^{2}=0.7218\right)$ \\
$\mathrm{C}_{36}$ & 0.0001 & 2.61 & $\left(\mathrm{C}_{36}\right)=9.45 \mathrm{~A}+10.65 \mathrm{~B}\left(\mathrm{R}^{2}=0.7497\right)$ \\
$\mathrm{C}_{38}$ & 0.0001 & 3.10 & $\left(\mathrm{C}_{38}\right)=10.88 \mathrm{~A}+12.28 \mathrm{~B}\left(\mathrm{R}^{2}=0.6868\right)$ \\
$\mathrm{C}_{40}$ & 0.0001 & 3.13 & $\left(\mathrm{C}_{40}\right)=7.97 \mathrm{~A}+9.06 \mathrm{~B}\left(\mathrm{R}^{2}=0.7032\right)$ \\
$\mathrm{C}_{42}$ & 0.0001 & 2.01 & $\left(\mathrm{C}_{42}\right)=5.52 \mathrm{~A}+6.12 \mathrm{~B}+0.23 \mathrm{AB}-1.55 \mathrm{AB}(\mathrm{A}-\mathrm{B})\left(\mathrm{R}^{2}=0.8599\right)$ \\
$\mathrm{C}_{44}$ & 0.0001 & 1.75 & $\left(\mathrm{C}_{44}\right)=5.38 \mathrm{~A}+5.96 \mathrm{~B}+0.052 \mathrm{AB}-1.35 \mathrm{AB}(\mathrm{A}-\mathrm{B})\left(\mathrm{R}^{2}=0.8826\right)$ \\
$\mathrm{C}_{46}$ & 0.0001 & 1.64 & $\left(\mathrm{C}_{46}\right)=6.48 \mathrm{~A}+7.14 \mathrm{~B}\left(\mathrm{R}^{2}=0.8364\right)$ \\
$\mathrm{C}_{48}$ & 0.0054 & 1.40 & $\left(\mathrm{C}_{48}\right)=9.37 \mathrm{~A}+9.65 \mathrm{~B}\left(\mathrm{R}^{2}=0.3740\right)$ \\
$\mathrm{C}_{50}$ & 0.0001 & 2.03 & $\left(\mathrm{C}_{50}\right)=13.61 \mathrm{~A}+12.55 \mathrm{~B}\left(\mathrm{R}^{2}=0.6940\right)$ \\
$\mathrm{C}_{52}$ & 0.0001 & 4.41 & $\left(\mathrm{C}_{52}\right)=15.03 \mathrm{~A}+11.18 \mathrm{~B}\left(\mathrm{R}^{2}=0.8668\right)$ \\
$\mathrm{C}_{54}$ & 0.0001 & 7.69 & $\left(\mathrm{C}_{54}\right)=7.31 \mathrm{~A}+4.92 \mathrm{~B}\left(\mathrm{R}^{2}=0.7892\right)$ \\
\hline $\mathrm{All}$ & &
\end{tabular}

All determinations were carried out in triplicate

*Values of "Prob > F" less than 0.05 indicate model terms are significant.

**The equation in terms of coded factors can be used to make predictions about the response for given levels of each factor. The coded equation is useful for identifying the relative impact of the factors by comparing factor coefficients. ***A: added tallow coefficient and B: butter coefficient.

TABLE 6. Analysis of variance according to response surface methodology for the effect of adding different contents of bovine tallow to butter on $\mathrm{S}$-value equations $(\mathrm{P}<0.05)$

\begin{tabular}{|c|c|c|c|}
\hline S-value equations & Prob $>F^{*}$ & $\% \mathrm{C.V}$ & L_Pseudo equation** \\
\hline $\mathrm{S} 1 * * * *$ & 0.0001 & 1.10 & $(\mathrm{~S} 1)=94.18 \mathrm{~A}^{* * *+99.27 \mathrm{~B} * * *\left(\mathrm{R}^{2}=0.7692\right)}$ \\
\hline S2 & 0.0016 & 0.32 & $(\mathrm{~S} 2)=100.76 \mathrm{~A}+99.95 \mathrm{~B}\left(\mathrm{R}^{2}=0.4618\right)$ \\
\hline $\mathrm{S} 3$ & 0.0001 & 2.51 & $(\mathrm{~S} 3)=86.73 \mathrm{~A}+96.96 \mathrm{~B}\left(\mathrm{R}^{2}=0.7389\right)$ \\
\hline S4 & 0.0001 & 0.87 & $(\mathrm{~S} 4)=104.54 \mathrm{~A}+99.72 \mathrm{~B}\left(\mathrm{R}^{2}=0.8096\right)$ \\
\hline S5 & 0.0001 & 2.59 & $(\mathrm{~S} 5)=86.21 \mathrm{~A}+96.47 \mathrm{~B}\left(\mathrm{R}^{2}=0.7295\right)$ \\
\hline
\end{tabular}

All determinations were carried out in triplicate

*Values of "Prob > F" less than 0.05 indicate model terms are significant.

**The equation in terms of coded factors can be used to make predictions about the response for given levels of each factor. The coded equation is useful for identifying the relative impact of the factors by comparing factor coefficients. $* * * A$ : added tallow coefficient and B: butter coefficient.

****S-value equations according to TAG percentages in ISO 17678 IDF 202:S1 (oil seeds, olive and fish oil), S2 (Coconut and palm kernel fat), S3 (Palm oil and beef tallow), S4 (Lard), S5 (Total).

of adding various contents of bovine tallow to butter on the significant ratio changes between different triacylglycerol percentages and also based on the ratio between the triacylglycerol percentages in pure butter, changes in the ratio contents of $\mathrm{C}_{52} / \mathrm{C}_{50}, \mathrm{C}_{52} /$ $\mathrm{C}_{54}, \mathrm{C}_{50} / \mathrm{C}_{54}, \mathrm{C}_{46} / \mathrm{C}_{54}, \mathrm{C}_{46} / \mathrm{C}_{42}, \mathrm{C}_{46} / \mathrm{C}_{44}, \mathrm{C}_{50} / \mathrm{C}_{46}, \mathrm{C}_{50} / \mathrm{C}_{48}$, $\mathrm{C}_{52} / \mathrm{C}_{48}$ and $\mathrm{C}_{52} / \mathrm{C}_{46}$, triacylglycerols could show an adulteration level in butter including bovine tallow in amounts above $1 \%, 5 \%, 2 \%, 2 \%, 15 \%, 15 \%, 2.8 \%$, $2.8 \% 1.7 \%$ and $1.5 \%$, respectively, in the sample.

\subsection{Relationship between triglycerides, fatty acids and other factors in butter}

In addition to studying the factors together in determining adulteration in butter, the correlation among different factors was also identified. If the collection of significant fatty acids of $\mathrm{C}_{4: 0}, \mathrm{C}_{6: 0}, \mathrm{C}_{8: 0}$,
$\mathrm{C}_{10: 0}, \mathrm{C}_{10: 1}, \mathrm{C}_{12: 0}, \mathrm{C}_{13: 0}, \mathrm{C}_{14: 0}, \mathrm{C}_{14: 1}, \mathrm{C}_{16: 0}, \mathrm{C}_{18: 0}$ and $\mathrm{C}_{18: 1 \mathrm{C}}$ is applied to evaluate adulteration content, the content of bovine tallow above $4 \%$ in butter will be detectable. But triacylglycerol collections with molecular weights of 40, 42, 46, 50, 52 and 54 could indicate the content of bovine tallow above $1 \%$ in butter. Therefore, the collection of these significant fatty acids and triacylglycerols resulted in the capability of adulteration determination in butter including bovine tallow content above $1 \%$. The collection of $\mathrm{C}_{52} / \mathrm{C}_{50}, \mathrm{C}_{52} / \mathrm{C}_{54}, \mathrm{C}_{50} / \mathrm{C}_{54}$ and $\mathrm{C}_{46} / \mathrm{C}_{54}$ triacylglycerol ratios had the ability to determine bovine tallow added above $1 \%$ As well.

The correlation among fatty acids, triacylglycerols and sterols indicated that $\mathrm{C}_{14: 1}$ fatty acid made the highest correlation with $\mathrm{C}_{42}(+0.78), \mathrm{C}_{44}$ $(+0.80), \mathrm{C}_{46}(+0.80)$ and $\mathrm{C}_{52}(-0.76)$ triacylglycerols and sterols $(+0.71)$. The results showed that $\mathrm{C}_{46}$ 
TABLE 7. Analysis of variance according to response surface methodology for the effect of adding different amounts of bovine tallo to butter on the ratio between triglycerides $(\mathrm{P}<0.05)$

\begin{tabular}{lccl}
\hline Parameters & Prob $>\mathbf{F}^{*}$ & \% C.V & \multicolumn{1}{c}{ L_Pseudo equation** } \\
\hline $\mathrm{C}_{52} / \mathrm{C}_{50}$ & 0.0001 & 3.03 & $\left(\mathrm{C}_{52} / \mathrm{C}_{50}\right)=1.11 \mathrm{~A}^{* * *}+0.89 \mathrm{~B}^{* * *}\left(\mathrm{R}^{2}=0.8796\right)$ \\
$\mathrm{C}_{52} / \mathrm{C}_{54}$ & 0.0132 & 5.19 & $\left(\mathrm{C}_{52} / \mathrm{C}_{54}\right)=2.06 \mathrm{~A}+2.26 \mathrm{~B}\left(\mathrm{R}^{2}=0.3014\right)$ \\
$\mathrm{C}_{50} / \mathrm{C}_{54}$ & 0.0001 & 6.78 & $\left(\mathrm{C}_{50} / \mathrm{C}_{54}\right)=1.85 \mathrm{~A}+2.52 \mathrm{~B}\left(\mathrm{R}^{2}=0.7460\right)$ \\
$\mathrm{C}_{46} / \mathrm{C}_{54}$ & 0.0001 & 7.58 & $\left(\mathrm{C}_{46} / \mathrm{C}_{54}\right)=0.87 \mathrm{~A}+1.42 \mathrm{~B}\left(\mathrm{R}^{2}=0.8527\right)$ \\
$\mathrm{C}_{46} / \mathrm{C}_{42}$ & 0.0163 & 1.84 & $\left(\mathrm{C}_{46} / \mathrm{C}_{42}\right)=1.19 \mathrm{~A}+1.16 \mathrm{~B}-0.12 \mathrm{AB}\left(\mathrm{R}^{2}=0.3652\right)$ \\
$\mathrm{C}_{46} / \mathrm{C}_{44}$ & 0.0077 & 1.28 & $\left(\mathrm{C}_{46} / \mathrm{C}_{44}\right)=1.22 \mathrm{~A}+1.20 \mathrm{~B}-0.78 \mathrm{AB}+0.15 \mathrm{AB}(\mathrm{A}-\mathrm{B})\left(\mathrm{R}^{2}=0.4928\right)$ \\
$\mathrm{C}_{50} / \mathrm{C}_{46}$ & 0.0001 & 2.92 & $\left(\mathrm{C}_{50} / \mathrm{C}_{46}\right)=2.10 \mathrm{~A}+1.76 \mathrm{~B}\left(\mathrm{R}^{2}=0.8433\right)$ \\
$\mathrm{C}_{50} / \mathrm{C}_{48}$ & 0.0001 & 1.57 & $\left(\mathrm{C}_{50} / \mathrm{C}_{48}\right)=1.45 \mathrm{~A}+1.30 \mathrm{~B}\left(\mathrm{R}^{2}=0.8783\right)$ \\
$\mathrm{C}_{52} / \mathrm{C}_{48}$ & 0.0001 & 4.48 & $\left(\mathrm{C}_{52} / \mathrm{C}_{48}\right)=1.60 \mathrm{~A}+1.16 \mathrm{~B}\left(\mathrm{R}^{2}=0.8837\right)$ \\
$\mathrm{C}_{52} / \mathrm{C}_{46}$ & 0.0001 & 5.67 & $\left(\mathrm{C}_{52} / \mathrm{C}_{46}\right)=2.31 \mathrm{~A}+1.56 \mathrm{~B}\left(\mathrm{R}^{2}=0.8734\right)$ \\
\hline $\mathrm{A}_{2}$ & &
\end{tabular}

All determinations were carried out in triplicate

*Values of "Prob > F" less than 0.05 indicate model terms are significant.

**The equation in terms of coded factors can be used to make predictions about the response for given levels of each factor. The coded equation is useful for identifying the relative impact of the factors by comparing factor coefficients.

***A: added tallow coefficient and B: butter coefficient.

triacylglycerol also had the highest correlations with $\mathrm{C}_{8: 0}(+0.70), \mathrm{C}_{10: 0}(+0.70), \mathrm{C}_{12: 0}(+0.72), \mathrm{C}_{18: 0}(-0.71)$ and $\mathrm{C}_{18: 1 \mathrm{C}}(-0.72)$ fatty acids. Iodine value had the most positive correlations with $\mathrm{C}_{17: 0}, \mathrm{C}_{18: 0}$ and $\mathrm{C}_{18: 1 \mathrm{c}}$ (0.75) fatty acids. Among the triacylglycerols, $\mathrm{C}_{50}$, $\mathrm{C}_{52}$ and $\mathrm{C}_{54}$ had more positive correlations with saponification value (0.84), slip melting point (0.85) and a negative correlation with sterols $(-0.78)$ but $\mathrm{C}_{46}$ triacylglycerols had the best correlation with the ratio of $\mathrm{C}_{14: 0} / \mathrm{C}_{18: 0}$ fatty acids.

\section{DISCUSSION}

Acid, iodine and saponification values changed by increasing tallow percentage because other researchers believed acid value could change as the result of contamination during the preparation of samples but iodine and saponification value could change based on double bond and length of chain in fatty acids, respectively (Sulieman et al., 2013).

According to many researches, milk fat sterol sections have been used as an appropriate parameter for the identification of milk fat adulteration (Kamm et al., 2001). In the study on the examination of ghee samples purchased from the market, cholesterol (as the animal sterol index) content was lower and sitosterol was higher, indicating the presence of vegetable oil in these products (Amrutha Kala et al., 2016). According to other research, in the samples of butter adulterated with vegetable oils $(10 \%)$, in spite of an increase in phytosterol content and decrease in cholesterol, the sterol measurement was insufficient to verify the authenticity of the milk fat in butter (Soha et al., 2015). According to this study, it was also recognized that the sterol measurement was not an appropriate parameter to determine butter in combination with animal fat so other factors had to be assayed in this sample.

Regarding the fatty acid analysis, in research conducted by other researchers it was found that in bovine milk fat mixed with supplied fat or vegetable oil, short and medium-chain fatty acids decreased by small amounts and high-chain fatty acids increased. In this regard the amount of linoleic acid was not determined by adding buffalo supplied fat at 10\% into bovine milk fat but the amount of oleic acid in the pure fat of bovine milk was determined by adding 5\% buffalo supplied fat (Kumar et al., 2015). Also, our results showed that by increasing the fat percentage of bovine tallow in butter, the content of long-chain fatty acids increased. Some others have also considered fatty acids such as $\mathrm{C}_{4: 0}, \mathrm{C}_{12: 0}$ and $\mathrm{C}_{18: 2}$ as indicators to determine the type of fat and/or oil used for adulteration (Kamm et al., 2001). But according to our findings in this study, fatty acid percentage could not be considered as a sufficient indicator to determine adulteration in butter. In previous studies, it was also reported that the determination of fatty acids was not sufficient to evaluate milk fat adulteration in butter (Rutkowska and Adamska, 2011; Soha et al., 2015).

In addition to our study on the profile of each fatty acid, the ratio of the main fatty acids in pure sample and adulterated samples could be used as criteria to determine adulteration in butter fat which was similar to other researchers (Toppino et al., 1980). In other studies, aimed at determining, the adulteration of soya oil and buffalo supplied fat in bovine milk fat, the ratios $\mathrm{C}_{14: 0}$ to $\mathrm{C}_{18: 1}$ and $\mathrm{C}_{14: 0}$ to $\mathrm{C}_{18: 2}$ were applied and able to determine $78 \%$ of adulterated samples. In addition, when comparing samples of pure and adulterated milk fat by applying 
the ratios of sum of total fatty acids of $\mathrm{C}_{4: 0}$ to $\mathrm{C}_{14: 1}$ to the sum of total fatty acids of $\mathrm{C}_{15: 0}$ to $\mathrm{C}_{20: 0}$ and adversely, it was found that these ratios were effective for all levels of adulteration $(5,10$ and 15\%) in bovine milk fat and they were easily identified (Kumar et al., 2015). In another study, the analysis of fatty compositions of butter was performed in combination with margarine in various treatments and did not yield satisfactory results with the view of determination of adulterations because adding low percentages of oils and fats to a fatty acid profile similar to that of butter made it difficult to interpret the analysis. However, the ratio of $\mathrm{C}_{14: 0} / \mathrm{C}_{18: 2}$ and $\mathrm{C}_{18: 2} / \mathrm{C}_{18: 0}$ fatty acids could be applied successfully along with other analysis methods to detect butter adulterations (Fathiteel et al., 2014). In a general study to determine the authenticity of fats and oils by using a collection of 4 ratios of $\left(\mathrm{C}_{18: 0} / \mathrm{C}_{8: 0}\right),\left(\mathrm{C}_{14: 0} /\right.$ $\left.\mathrm{C}_{18: 0}\right),\left(\mathrm{C}_{6: 0}+\mathrm{C}_{8: 0}+\mathrm{C}_{10: 0}+\mathrm{C}_{12: 0} / \mathrm{C}_{18: 0}\right),\left(\mathrm{C}_{18: 1} / \mathrm{C}_{18: 0}\right)$ fatty acids, a detection of $10 \%$ bovine tallow in milk fat was possible (Ulberth and Buchgraber, 2000).

With respect to the triacylglycerol percentage, our results were similar to other researcher who studied the evaluation of vegetable oil and animal fat in ghee, where the contents of $\mathrm{C}_{50}, \mathrm{C}_{52}, \mathrm{C}_{54}$ triacylglycerols increased and were beyond the limits of total S-value contents (Destaillats et al., 2006). The Triacylglycerols in ghee samples purchased from market were also evaluated by other researchers where adulteration at a 5\% level in milk fat indicated changes in the $\mathrm{C}_{50}, \mathrm{C}_{52}, \mathrm{C}_{54}$ triacylglycerols. The approximate content of foreign fat in milk fat was determined using the total $\mathrm{S}$-value equation as well. (Amrutha Kala et al., 2016). In our study, the $\mathrm{S}$-value and the ratios of triacylglycerols had the ability to determine the level of bovine tallow added to butter. The advantage of a triacylglycerol analysis in comparison with the fatty acid profile was that specially controlled spatial distribution of fatty acid components on the glycerol backbone was protected genetically and therefore, the content of intact triacylglycerol information was usually higher (Ulberth and Buchgraber, 2000). However, it has been suggested that the triacylglycerol data for natural oils with fatty acid data should be used as complementary so that significant diagnostic models are obtained (Kaufmann and Herslöf, 1991).

\section{CONCLUSION}

According to this research, multiple identification tests and sensitive analyses are a basis for the determination of pure butter authenticity in combination with bovine tallow, which verify the necessity for precise assessments with the aim of adulteration traceability. Therefore, all assessment methods together were found to be important for the determination of purity and in this regard, the identification of fatty acid profile, sterol composition and triacylglycerol structure can entail a complete and comprehensive assessment together for the determination of butter in combination with bovine tallow. $\mathrm{T}$ The successive use of fatty acid composition and triacylglycerols resulted in the capability to determine adulteration in butter including bovine tallow above $1 \%(\mathrm{w} / \mathrm{w})$.

\section{REFERENCES}

Amrutha Kala AL, Sabeena K, Pramod Havanur P. 2016. Determination of triacylglycerol and sterol components of fat to authenticate ghee based sweets. J. Food Sci. Technol. 53 (4), $2144-2147$. https://doi.org/10.1007/s13197-016-2182-3

AOCS. Saponification value. American Oil Chemists' Society. Method no. 1998/Cd 3b-76

AOCS. Slip melting point. American Oil Chemists' Society. Method no.1997b/Cc 3-25

Codex Stan. Olive oils and olive pomace oils. Codex Stan 2015/33

Codex Stan. Butter. Codex Stan 2010/279

Commission Regulation (EC). Determining sitosterol or stigmasterol in butter or concentrated butter by capillary- column gas chromatography. Commission Regulation (EC) no.2008/273

Dardiri MM. 1985. Laboratory Experiments for Food Analysis. Food Science and Technology, University of Gezira.

Destaillats F, Wispelaere M, Joffre F, Golay PA, Hug B, Giuffrida F. 2006. Authenticity of milk fat by fast analysis of triacylglycerols application to the detection of partially hydrogenated vegetable oils. J. Chromatogr. A 1131, 227-234. https://doi.org/10.1016/j.chroma.2006.07.040

Fathiteil R, Hessari J, Azadmmard Damirchi S, Nemati M, Peighambardoost SH, Raafat SA. 2014. Determination of margarine in butter. Iran J. Food Sci. Technol. Res. 10, 85-90.

Hocquette JF, Gigli S. 2005. Indicators of milk and beef quality. Wageningen Academic Publishers, Wageningen, Netherlands. https://doi.org/10.3920/978-90-8686-537-6

IDF. 2008. Nutritional quality of milk fat. Brussels, Belgium: International Dairy Federation.

Iranian National Standard. Pasteurized butter- Test methodSpecifications. Method no. 2007/162

ISO. Animal and vegetable fats and oils- Determination of iodine value. Method no. 2013/3961

ISO. Animal and vegetable fats and oils- Determination of refractive index. Method no. 2000/6320

ISO. Butter-Determination of firmness. Method no. 2005/16305

ISO. Milk fat-Determination of the fatty acid composition by gas-liquid chromatography. Method no. 2002/15885

ISO. Milk and milk products-Determination of milk fat purity by gas chromatographic analysis of triglycerides. Method no. $2010 / 17678$

Jensen RG. 2002. Invited Review: The composition of bovine milk lipids: January 1995 to December 2000. J. Dairy Sci. 85, 295-350. https://doi.org/10.3168/jds.S0022-0302(02) 74079-4

Kamm W, Dionisi F, Hischenhuber C, Engel KH. 2001. Authenticity of fats and oils. Food Rev. Int. 17, 249-290.

Kaufmann P, Herslöf BG. 1991. A multivariate identification of natural triglyceride oils. Eur. J. Lipid Sci. Technol. 93, 179-183. https://doi.org/10.1002/lipi.19910930504

Kumar A, Upadhyay N, Padghan PV, Gandhi K, Lal D, Sharma V. 2015. Detection of vegetable oil and animal depot fat adulteration in anhydrous milk fat (Ghee) using fatty acid composition. MOJ. Food Processing Technol. 1, 1-8. https:// doi.org/10.15406/mojfpt.2015.01.00013

Mahlenbacher CV. 1960. The Analysis of Fats and Oils. Garrard Publishing, Champaign, Illinois. https://doi.org/10.1002/ lipi.19610630220

Montealegre C, Marina Alegre ML, Garcia Ruiz C. 2010. Traceability markers to the botanical origin in olive oils. J. Agric. Food Chem. 58, 28-38. https://doi.org/10.1021/ jf902619z

Nollet LML, Toldra F. 2010. HandBook of Dairy Foods Analysis. Boca Raton, London, New York. 
Palmquist DL. 2006. Milk Fat: Origin of fatty acids and influence of nutritional factors there on, in Fox PF, McSweeney PLH (Eds.) Advanced dairy chemistry, 3nd ed, Vol 2. Lipids, Springer, New York, pp. 43-92. https://doi. org/10.1007/0-387-28813-9_2

Rutkowska J, Adamska A. 2011. Fatty acid composition of butter originated from North-Eastern region of Poland. Pol. J. Food Nutr. Sci. 61, 93-187. https://doi.org/10.2478/ v10222-011-0020-x

Soha S, Mortazavian AM, Piravi-Vanak Z, Mohammadifar MA, Sahafar H, Nanvazadeh S. 2015. Adequacy of the measurement capability of fatty acid compositions and sterol profiles to determine authenticity of milk fat through formulation of adulterated butter. Recent Pat. Food Nutr. Agric. 7 (2), 134-140.

Sulieman AME, Mohammed MB, Ali AO. 2013. Physicochemical and sensory properties of traditionally and laboratory made ghee (Samin) of the Sudan. Int. J. Food Sci. Nutr. Eng. 3 (1), 7-11.

Toppino PM, Contarini G, Trauersi AL, Amelotti G, Gargario A. 1980. Gas chromatographic parameters of genuine butter. Riv. Ital. Sostanze Gr. 59, 592.

Ulberth F, Buchgraber M. 2000. Authenticity of fats and oils. Eur. J. Lipid Sci. Technol. 102, 687-694. https:// doi.org/10.1002/1438-9312(200011)102:11<687::AIDEJLT687>3.0.CO;2-F 